\title{
Communication
}

[Comunicação]

\section{Isolation and genetic stability of an infectious bronchitis virus strain (IBV)}

\author{
[Isolamento e estabilidade genética de uma cepa do vírus da bronquite infecciosa (IBV)] \\ C.G. Pereira, G.L. Saraiva, M.R. Santos, V.S. Assao, J.L.R. Fietto, G.C. Bressan, \\ M.R. Almeida, M.A.S. Moreira, A. Silva Júnior ${ }^{*}$ \\ Universidade Federal de Viçosa - Viçosa, MG
}

\begin{abstract}
Infectious bronchitis virus (IBV) is a member of the Coronaviridae family that represents a major cause of economic losses in the poultry industry, affecting the performance of breeders, laying hens and broiler chickens (Cavanagh, 2007). The difficulty in controlling avian infectious bronchitis (IB) is associated with the multiplicity of IBV variants that arise or are unpredictably introduced into poultry flocks. Despite the systematic use of vaccination, the disease has not yet been satisfactorily controlled (Jackwood $e t$ al., 2012).
\end{abstract}

A wide variety of techniques are available to detect the IBV, however it is common to include the isolation and molecular characterization of the virus responsible for the clinical signs observed in the field. The isolation of IBV is performed through inoculation of the clinical specimens into embryonated eggs of SPF chickens, including three or more serial passages in embryos. The isolation has the advantage of increasing the viral titer and improves the sensitivity of molecular toll, subsequently; the genomic segment can be amplified and sequenced for characterization and genotyping (Wit, 2000).

Genetic alterations in IBV genomic RNA after isolation are documented; however, this variation is further studied after a greater number of passages for attenuation of the vaccine strain (e.g., H120 vaccine). In the literature, there are few information about the genetic changes in the IBV genomic RNA after the routine method of isolation and it is possible that the reliability of

Recebido em 12 de abril de 2017

Aceito em 21 de dezembro de 2017

*Autor para correspondência (corresponding author)

E-mail: abelardo.junior@ufv.br the results of viral molecular characterization may be affected. The most studied gene is the S1 subunit of the spike protein and can change during adaptation to the host (Cavanagh et al., 2005). This case report aims to characterize partial sequence of a strain of IBV after three passages in embryonated eggs.

At the start of 2013, 18-day-old chicks belonging to a single batch of 36,000 breeding hens, located in the state of Minas Gerais, Brazil, presented clinical signs such as sneezing, uricosis, and $12 \%$ mortality. Samples of kidneys of 10 chicks were obtained and stored at $-80^{\circ} \mathrm{C}$. The commercial batch was vaccinated at 2 days of age with IBV Nobilis® IB Ma5 (MSD, Animal health). The Ma5 vaccine was produced with a biological clone non-pathogenic IBV strain, which was replicated in the tissues of SPF chicken embryos and marketed as a live vaccine. The same batch of the vaccine IBV Nobilis® IB Ma5 (MSD Animal Health) used in the chicks was sequenced and analyzed in this study. This project complied with the principles of the Commission for Ethics in Animal Experimentation of the Universidade Federal de Viçosa under protocol n ${ }^{\circ} 74 / 2013$.

The isolation technique used was the standard (OIE, 2013) with some changes. Briefly, a suspension of $200 \mu \mathrm{L}$ of clinical specimens from kidneys was inoculated into embryonated chicken SPF eggs and incubated for 9-11 days. Approximately $1 \mathrm{ml}$ of the liquid chorioallantoic (LC) of each infected and living embryo was collected 24 hours after inoculation to form a pool in each of the blind passages. The LC harvested from embryos infected after the third 
passage was stored at $-80^{\circ} \mathrm{C}$ and embryos were returned to the incubator for an additional 7 days post inoculation (PI) with the drilling of the shells properly sealed. After this period, the infected embryos and controls were cooled to $4^{\circ} \mathrm{C}$ overnight before analyzing.

The RNA extraction was performed using Trizol Reagent (Invitrogen TM) following the manufacturer's recommendations. The genetic material was obtained directly from the kidneys and from the bottle of the vaccine resuspended in $2 \mathrm{~mL}$ of sterile water. The LC of the embryos was previously clarified $(1,000 \mathrm{x}$ g for 15 minutes at $\left.4^{\circ} \mathrm{C}\right)$.

IBV RNA was transcribed to cDNA using oligonucleotide S1oligo3' (12) and the enzyme SuperScript ${ }^{\circledR} \quad$ III Reverse Transcriptase (Invitrogen TM) according to manufacturer's recommendations. The reactions of nested RTPCR were performed according to previously described protocols (Kwon et al., 1993; Keeler-Jr et al., 1998). The amplification of the genomic target segment of the IBV was performed in triplicate for each sample in the same run, and the products were sequenced separately. Positive samples for the IBV S1 gene showed a fragment of approximately 600 base pairs (bp), belonging to the hypervariable regions I and II of the S1 protein.

The RT-PCR products were sequenced by Macrogen Inc. (Seoul, Korea), and the contigs of the nucleotide sequences of the $\mathrm{S} 1$ gene were assembled using CLC Genomics Workbench version 7.5. The obtained partial sequences of S1 gene were submitted to the Genbank (http://www.ncbi.nlm.nih.gov/Genbank) with the following accession numbers: KU736747, KU736755, KU736763.

BLAST software was used to verify the identity of the sequences obtained in this study with homologous sequences of IBV. The database was aligned using the CLUSTALW algorithm and the phylogenetic analysis was performed using MEGA version 6. The sequences were grouped by the neighbor-joining distance method and Kimura's two parameter substitution model. The statistical support for the phylogenetic tree was calculated using 10,000 bootstrap replicates. After obtaining the phylogenetic tree, reference sequences belonging to the GI-1 group (Massachusetts strains) were chosen to analyze the polymorphs and homology found in these sequences using MEGA software.

At necropsy of the chicks, deposition of urates was observed, as well as enlargement of the kidneys, hemorrhagic and/or pale kidneys and retention of urate in the ureters. Clinical manifestations and macroscopic lesions in infected chicks are the same as those described for the infection of IBV (Zhou et al., 1998), these results showed that the commercial vaccine may not provide adequate protection from a field challenge as related in others works (Leyson et al., 2016).

The infected embryos and the embryos in the control group were analyzed after the third serial passage of the inoculum prepared from clinical specimens of kidney. At 7 days PI the embryos of the control group exhibited normal development (Figure 1A), whereas the infected embryos exhibited lesions characteristic of IBV replication as dwarfism, winding and hyperemia (Figure 1B).

The alignment of S1 fragments of the vaccine strain Ma5 with that obtained directly from kidney samples showed changes in 15 nucleotides. These polymorphisms were reflected in seven amino acids alterations in the analyzed fragment, four of which were similar to those of the pathogenic strain M41 (Genbank accession number: M21883): $101(\mathrm{H}), 130(\mathrm{~F})$, $179(\mathrm{E})$ and $205(\mathrm{~K})$ (Table 1). Conversely, the IBV isolated from the kidney after the third passage exhibited changes in 12 nucleotides compared to that obtained directly from kidney tissue. The polymorphisms result in a change of six amino acids at the positions: T69I, D73G, H101Y, G118V, F130S and K205R (Table 1). 

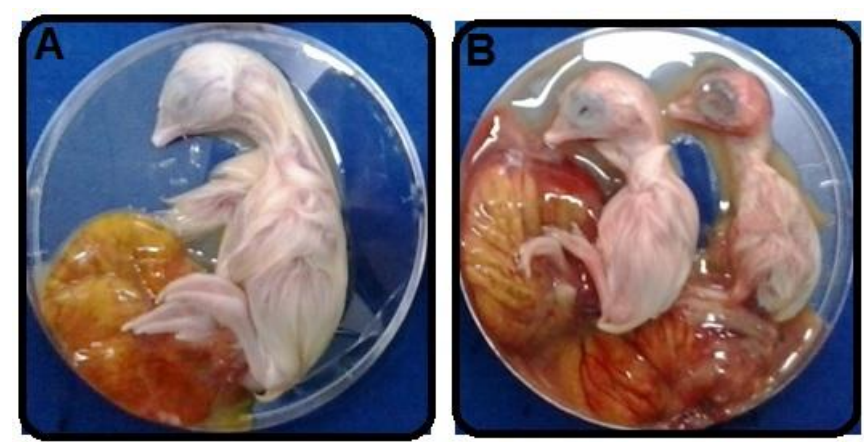

Figure 1. IBV isolation in SPF embryonated chicken eggs. (A) Uninfected embryos with normal development, (B) Embryos infected after the third passage exhibiting dwarfism, winding and hyperemia. Embryos were rolled out for presentation.

Table 1. Analysis of partial amino acid sequences of the $\mathrm{S} 1$ gene. The positions in amino acid sequences are shown for the pathogenic strain M41 (M21883), vaccine strains Ma5 (KU736747) and H120 (M21970), IBV strain detected directly from the kidney (KU736755) and IBV strain after isolation (KU736763). Changes in the amino acid sequences between KU736755 and KU736763 strains are highlighted in bold

\begin{tabular}{ccccccccccccccccc}
\hline $\begin{array}{c}\text { Amino acid } \\
\text { position/ } \\
\text { strains }\end{array}$ & 43 & 63 & 66 & 69 & 73 & 101 & 117 & 118 & 128 & 129 & 130 & 131 & 179 & 203 & 205 \\
\hline M41 & H & P & I & T & G & H & Y & D & K & N & F & L & E & K & K \\
H120 & H & S & T & I & G & Y & H & V & Q & H & S & I & E & E & R \\
Ma5 & H & S & T & I & G & Y & H & G & Q & H & S & I & A & E & R \\
KU736755 & Q & S & T & T & D & H & H & G & Q & H & F & I & E & E & K \\
KU736763 & Q & S & T & I & G & Y & H & V & Q & H & S & I & E & E & R \\
\hline
\end{tabular}

Polymorphisms in the S1 spike glycoprotein can modify the binding capacity to host tissue and the antigenicity. Promkuntod et al. (2014), describe that modifications between residues 1969 in the S1 gene may influence the proteins to bind to host receptors. Modification of tyrosine by histidine in residue 43 in $\mathrm{S} 1$ protein, increased the capacity of the protein to bind to host trachea in a test using recombinant proteins drawn from the sequence of strain ArkDPI (Leyson et al., 2016). We compared the partial sequence of S1 protein in vaccine Ma5 with the sequence isolated from tissue and LC, and we identified a modification of histidine (polar basic residue) to glutamine (polar neutral residue) in position 43. The sample identified directly from the tissue, had a difference in the sequence when compared to strain Ma5, the non-polar isoleucine residue was modified to a neutral polar threonine residue in position 69 .

After the sequencing, we observed that the viral strains identified directly from the tissue and after isolation showed high identity with strains of serotype Massachusetts, with values ranging from 95.53 to $99.75 \%$ (Figure 2). The comparison between the field strain (KU736755) and the isolated virus (KU736763) showed $97.93 \%$ of homology. The KU736755 strain (kidney) is genetically more correlated with the M41 (97.08\%) and Ma5 strain (97.25\%). However, the same strain isolated by only three passages in embryonated eggs (KU736763) appeared to be genetically more correlated with the H120 attenuated vaccine strain $(98.63 \%)$. In comparison to the $\mathrm{S} 1$ sequence obtained directly from the tissue, the S1 sequence of isolated IBV exhibited six amino acid changes. These amino acids were similar to the vaccine strain H120. It is important to note that only hypervariable regions I and II of the S1 gene were evaluated in this study; therefore, comparisons are limited to this segment. However, the IBV S1 sequences deposited in the nucleotide databases are partial, including only the hypervariable regions of the protein. The tendency to obtain partial sequences may be due to the sequencing of a complete S1 sequence that is laborious; usually, isolation in successive passages is necessary when working with embryonated eggs. 


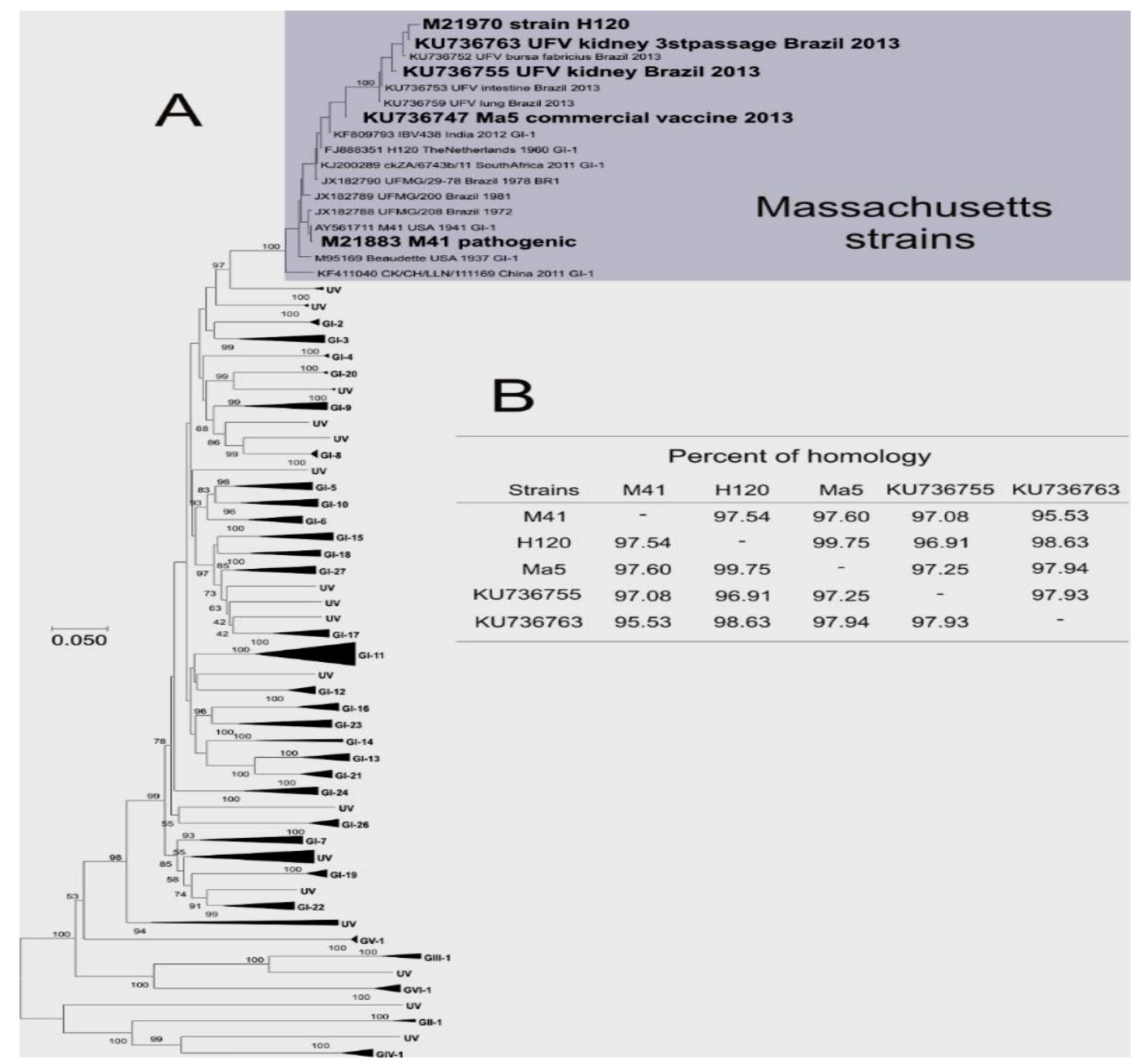

Figure 2. A) Phylogenetic analysis of S1 partial sequences of IBV. The neighbor-joining phylogenetic tree shows the genetic relationship between the IBV Massachusetts strains, which includes a clinical sample sequenced directly from the kidney (KU736755), the same IBV strain isolated from SPF embryonated chicken eggs and the sequence of a Ma5 vaccine (KU736747). The numbers beside the nodes correspond to bootstrap values. B) Percentage of homology between reference sequences extracted from the phylogenetic tree (in bold). The reference sequences are the pathogenic strain M41 (M21883), vaccine strains H120 (M21970) and Ma5 (KU736747), the strain identified directly from kidneys (KU736755) and strain isolated from embryonated chicken eggs (KU736763).

We showed a significant variation in viral sequence after isolation in embryonated eggs. These results could be explained by two hypotheses. The first hypothesis is that coronavirus has been showing a quick evolution, since RNA-dependent RNA polymerase has limited capacity of correction, which can complete mutation in single progenitor genome (Jackwood et al., 2012). After three passages in embryonated eggs, the changes in nucleotide sequence may be due to failure of the RNAdependent RNA polymerase. The second hypothesis seems more probable:that the rapid evolution rates may allow the IBV exist as a viral subpopulation; which comprises of a mixed population of nucleotide sequences, consisting of the total number of variations that can exist for any given viral species (Domingo et al., 1998). Some studies showed that commercial chickens were infected with different viral subpopulation (Pereira et al., 2016). The viral subpopulation isolated after passages in embryonated eggs may have been the subpopulation that did not predominate in renal tissues of the chickens. 
As demonstrated in this study, obtaining the genomic sequence of IBV after isolation in embryonated eggs, using even a few passages, can lead to significant variation in these data. The exact mechanisms of viral mutation is not fully understood, but other studies should be done for a better understanding. The results this work may auxiliary in the development of new vaccines against field IBV and in the diagnostic methods.

\section{ACKNOWLEDGMENTS}

This research was supported by the Brazilian Government Agencies CAPES, CNPq and FAPEMIG.

Keywords: infectious bronchitis virus, isolation, characterization, stability

\section{RESUMO}

$O$ vírus da bronquite infecciosa (IBV) é um importante patógeno respiratório presente na avicultura comercial e tem provocado grandes perdas econômicas em todo o mundo. A vacinação é realizada pela indústria produtora de aves, mas continuam surgindo novos sorotipos e variações antigênicas, dificultando o controle de IBV. Nós realizamos uma caracterização molecular de uma cepa de IBV obtida diretamente de tecidos e comparamos com a mesma cepa que havia sido passada três vezes em ovo embrionado. Nós mostramos uma variação significante na sequência viral depois de ter sido isolada em ovo embrionado.

Palavras-chave: vírus da bronquite infecciosa, isolamento, caracterização, estabilidade

\section{REFERENCES}

CAVANAGH, D. Coronavirus avian infectious bronchitis virus. Vet. Res., v.38, p.281-297, 2007

CAVANAGH, D.; PICAULT, J.P.; GOUGH, R. et al. Variation in the spike protein of the 793/B type of infectious bronchitis virus, in the field and during alternate passage in chickens and embryonated eggs. Avian Pathol., v.34, p.20-25, 2005.

DOMINGO, E.; BARANOWSKI, E.; RUIZJARABO, C.M. et al. Quasispecies structure and persistence of RNA viruses. Emerg. Infect. Dis. J., v.4, p.521-527, 1998.

JACKWOOD, M.W.; HALL, D.; HANDEL, A. Molecular evolution and emergence of avian gammacoronaviruses. Infect. Genet. Evol., v.12, p.1305-1311, 2012.

KEELER-JR, C.L.; REED, K.L.; NIX, W.A.; GELB, J.JR. Serotype Identification of Avian Infectious Bronchitis Virus by RT-PCR of the Peplomer (S-1) gene. Avian Diseases, v.42, p.275-284, 1998.

KWON, H.M.; JACKWOOD, M.W.; GELB-JR, J. Differentiation of infectious bronchitis virus serotypes using polymerase chain reaction and restriction fragment length polymorphism analysis. Avian Dis., v.37, p.194-202, 1993.
LEYSON, C.; FRANÇA, M.; JACKWOOD, M.; JORDAN, B. Polymorphisms in the S1 spike glycoprotein of Arkansas-type infectious bronchitis virus (IBV) show differential binding to host tissues and altered antigenicity. Virology, v.498, p.218-225, 2016.

PEREIRA, C.G.; SARAIVA, G.L.; VIDIGAL, P.M. et al. Distribution of infectious bronchitis virus strains in different organs and evidence of vertical transmission in natural infection. Arch. Virol., v.161, p.3355-3363, 2016.

PROMKUNTOD, N.; EIJNDHOVEN, R.V., VRIEZE, G.; GRÖNE, A.; VERHEIJE, M.H. Mapping of the receptor-binding domain and amino acids critical for attachment in the spike protein of avian coronavirus infectious bronchitis virus. Virology, v.448, p.26-32, 2014.

WIT, J.J. Detection of infectious bronchitis virus. Avian Pathol., v.29, p.71-93, 2000.

WORLD ORGANIZATION FOR ANIMAL HEALTH [OIE]. Chapter 2. 3. 2. Avian Infectious Bronchitis. In: Manual of diagnostic tests and vaccines for terrestrial animals. 2013. Available

in: <http://www.oie.int/doc/ged/D7710.pdf >. Accessed in:10.Out.16.

ZHOU, J.Y.; YU, L.; HONG, J. Isolation and identification of chicken's infectious bronchitis nephritis virus. J. Zhejiang Univ., v.24, p.303307, 1998 . 